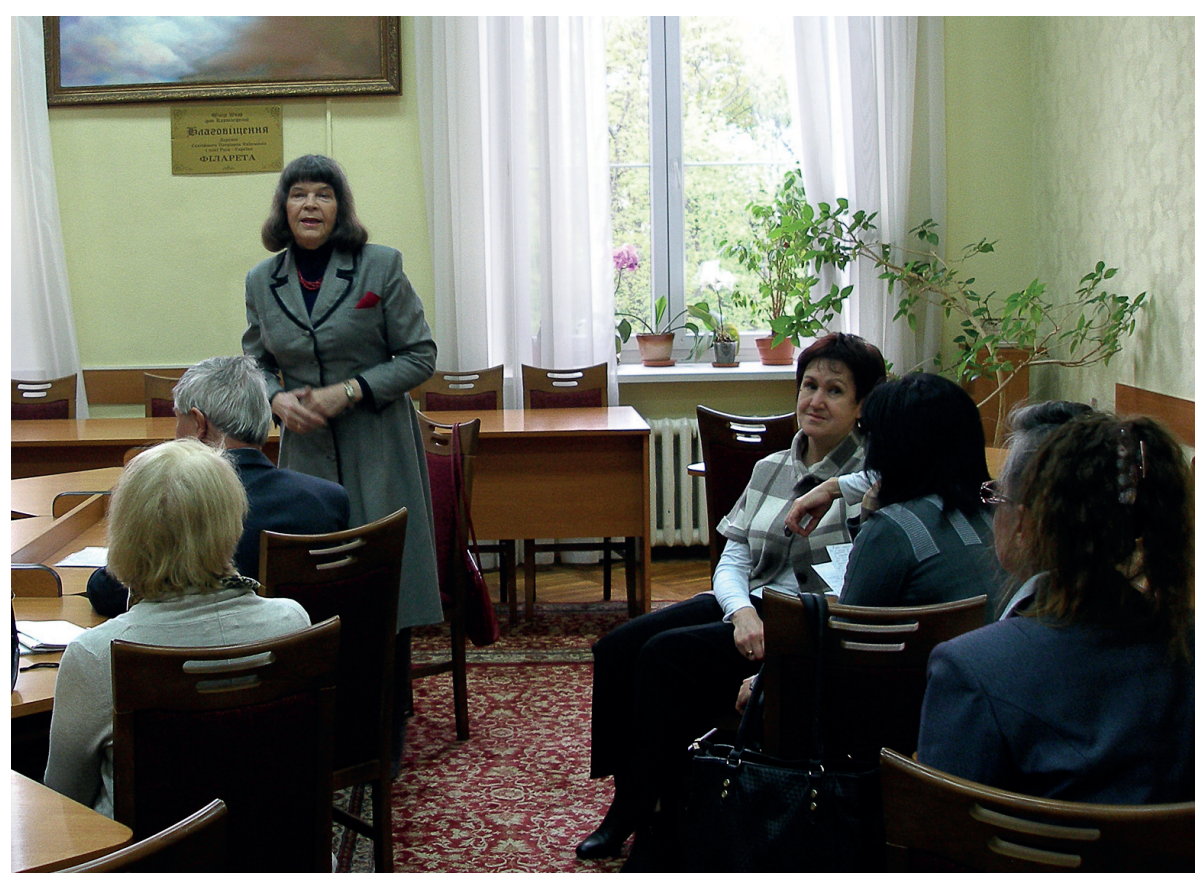

УДК: 167

\title{
Круглий стіл
}

\section{"ДОСЯГНЕННЯ ТА ПЕРСПЕКТИВИ СИНЕРГЕТИЧНИХ ДОСЛІДЖЕНЬ У ВІТЧИЗНЯНІЙ ГУМАНІТАРИСТИЦІ»}

(Київський національний університет імені Тараса Шевченка, 17 квітня 2016 року)

Ірина Добронравова, Любов Бевзенко, Лідія Богата, Людмила Горбунова, Ірина Доннікова, Юрій Мєлков, Віталій Надурак, Володимир Ратніков

В травні 2017 року виповниться 15 років з дати створення Українського синергетичного товариства. Готуючись до свого ювілею, члени цього товариства разом з кафедрою філософії та методології науки Київського національного університету імені Тараса Шевченка провели засідання круглого столу в межках міжннародної наукової конференції "Дні науки філософського факультету 2016», що тривала 20-21 квітня в червоному корпусі університету імені Шевченка. Тема цього засідання відповідна: "Досягнення та перспективи синергетичних досліджень у вітчизняній гуманітаристиці». Предметом обговорення були на- 
ступні актуальні проблеми: синергетика як трансдисциплінарний науковий проект, інтеграція теорії складності і теорії практик як перспектива розвитку синергетичного проекту в соціо-гуманітарній сфері, постнекласичне гуманітарне знання як рух до антропологічної складності, подолання дегуманізації гуманітарних наук, використання синергетичної методології для дослідження феномену суспільної моралі, методологічні можлливості синергетики в дослідженні освітніх практик, зокрема, трансформативного навчання дорослих.

Вела це засідання президент Украйнського синергетичного товариства професор Ірина Добронравова, доктор філософських наук, завідувачка кафедри фiлософії та методології науки КНУ імені Шевченка. Виклад матеріалів круглого столу ми починаємо з ї̈ вступного слова.

Ключові слова: синергетика, трансдисциплінарність, теорія складності, теорія практик, постнекласичне гуманітарне знання, Українське синергетичне товариство.

\section{Ірина Добронравова, модератор}

Українське синергетичне товариство створене як громадська національна організація науковців та викладачів вищої школи, політиків та громадських діячів та інших людей, зацікавлених у вирішенні проблем розвитку людства й модернізації українського суспільства на засадах синергетичної парадигми самоорганізації, - нової методології пізнання та практики. Установчий з'ізд відбувся в Києві 28 травня 2002 року. ${ }^{1}$

Основною метою Товариства був розвиток наукових засад синергетики для їх практичного застосування у різноманітних сферах суспільного життя. Консолідація в одній науковій спільноті вчених різних спеціальностей і професійних методологів науки мала сприяти руху від синергетичного витлумачення певних явищ дійсності як феноменів самоорганізації до втілення в практичній діяльності відповідних наукових здобутків.

На засіданні нашого круглого столу ми згадаємо низку таких наукових здобутків членів Українського синергетичного товариства та спробуємо накреслити перспективи його подальшої роботи.

\section{Трансдисциплінарність синергетики: вітчизняний досвід}

3 самого початку своєї роботи Українське синергетичне товариство виходило з трансдисциплінарності синергетики в обох розуміннях цього терміну. В одному з них трансдисциплінарність тлумачиться як наскрізне використання певних методологій в різних наукових дисциплінах, а в другому як вихід за межі будь-якої дисциплінарної науковості у життєсвіт людини (Трансдисциплинарность, 2015: 14-15).

\footnotetext{
${ }^{1}$ Дивіться це та інші вихідні настанови створення Українського синергетичного товариства на його сайті http://www. synergetic.org.ua
} 
Колись один з засновників синергетики Герман Гакен сказав, що синергетика росте звідусіль (Хакен, 2001). Він мав на увазі процеси, що відбуваються в науці: тільки но об’єкти наукового дослідження опиняються в умовах, що виходять за межі певних критичних значень, власне, в умовах нелінійності, вони виявляються предметом синергетики, оскільки в них розгортаються процеси самоорганізації. Деякі з цих процесів наука відкрила нещодавно (хімічний годинник, наприклад), але багато з них було описано науковцями досить давно (комірки Бенара - на початку XX століття, солітони - в середині XIX ). Ще більше з трактованого останнім часом як явища самоорганізації було відомо людству з давніх давен: полум'я свічок (синергетично зрозумілих як усамітнена хвиля), язики полум'я у вогнищах (теплові структури в плазмі), хвилі цунамі (солітони) та багато іншого. Світ живого - це світ самоорганізації: від утворення плям чи смуг на шкірі тварин до іонного обміну на мембранах клітин в організмах, від симбіозу рослин до квазіперіодичних коливань в системах популяцій «хижаки - жертви» в певних ареалах їх існування. Синергетичне вивчення самоорганізації живого тільки розпочато.

Життя людини, як з'ясувалось, є самоорганізацією і у внутрішньому світі ії психіки (це предмет вивчення психосинергетики), і у зовнішньому світі соціальних стосунків (соціосинергетика). Самоорганізація соціуму в його економічних засадах та політичних проявах призводить до появи соціальних інститутів, які здійснюють організаційні функції. Та за спиною організації завжди стоїть самоорганізація, якій організаційні зусилля можуть сприяти або заважати. В останньому випадку самоорганізація зрештою руйнує соціальні інститути, які не здатні до самоперетворення. Роль синергетики як науки як раз і полягає в тому, щоб неусувність процесів самоорганізації раціонально усвідомлювалась, а не нехтувалась. Без такого усвідомлення можливостей самоорганізації, яким треба сприяти, та ризиків, яких треба уникати, вона виступає на поверхні буття як революційні потрясіння або застійний занепад.

Так історично склалось, що розвиток синергетики та зусилля з популяризації іï ідей поєднались в останні десятиліття у зустрічному русі з процесами соціальної самоорганізації, які найбільш природним чином усвідомлюються в термінах синергетики.

Я, звичайно, маю на увазі обидва Майдани в українській новітній історії. Члени Українського синергетичного товариства не залишились осторонь ні щодо перебігу цих подій, ні щодо їх наукового пояснення. Так, Л.Д. Бевзенко стала доктором соціології в 2004 році на базі ії книжки про соціальну самоорганізацію, виданої в 2002 році (Бевзенко, 2002). Розвинуті в цій книжці ідеї про міф та гру як форми соціальної самоорганізації дозволили їй вже в 2005 році осмислити досвід першого Майдану (Бевзенко, 2005). 
У мене на час першого Майдану вже було разом з математиком Леонідом Фінкелем здійснено синергетичну трактовку математичного аналізу результатів президентських та парламентських виборів (Добронравова, Фінкель, 2003). На її основі середовище соціальної самоорганізації в Україні було визначено як динамічний хаос. Це надало можливість виробити спосіб поведінки для забезпечення утворення стійких структур як сприятливого перебігу подій в процесі соціальної самоорганізації (Добронравова, Фінкель 2005). Стійкі структури (фрактали) утворюються в динамічному хаосі в полі конкуренції атракторів, тому не усунення опонентів, а чесна конкуренція забезпечує стійкість політичної самоорганізації. Характерно, що досвід людства у розвитку демократії практично випрацював ті ж настанови толерантності, на які спрямовує синергетична теорія хаосу. Я навіть виступала по радіо «Ера», щоб популяризувати ці міркування. (Добронравова, 2006).

Я далека від думки, що тільки зусиллями Українського синергетичного товариства ідеї синергетики набули поширення в суспільній свідомості, але ці зусилля безумовно сприяли такому поширенню. Так що на час другого Майдану розуміння діяльності його учасників як самоорганізації було вже загальним уявленням. Подальша самоорганізація волонтерського руху підтримки захисників української незалежності на Донбасі була важливим чинником і розвитку громадянського суспільства в Україні і налаштування адекватних новим реаліям організаційних зусиль державних інституцій. Можна було б заперечити, що саме слово «самоорганізація» яскраво виявляє свій сенс, відповідний суспільним практикам, що сприяє їх усвідомленню, і синергетика тут ні до чого. Але поширення набувають і інші терміни синергетики, сенс яких не такий наочний. Так, розуміння нинішнього стану української політики як ситуації біфуркації озвучується політиками, і журналістами, далекими від теоретичних вишуканостей.

Вихід у життєсвіт синергетичних ідей як одна з ознак трансдисциплінарності синергетики відбувається не тільки у варіанті буремних подій становлення і захисту української державності. Наука, освіта та мистецтво - різні галузі культури також осмислюються за допомогою синергетичних ідей і реалізують їх у своїх практиках. I відбувається це на основі трансдисциплінарності методології синергетики, підкріпленої розробкою їі філософських засад. Доклали своїх зусиль до такої розробки і члени Українського синергетичного товариства.

В роботах I. М. Предборьскої (Предборська, 2003) синергетична проблематика знайшла своє відображення у формулюванні нерівноважної соціодинаміки - нової парадигмальної основи дослідження перехідних суспільств. 3 точки зору нерівноважної соціодинаміки універсальною, базовою подією, елементарним актом соціальної реальності в ії процесуальному ракурсі слід 
вважати не прогрес, розвиток, еволюцію тощо, а соціальну зміну. Це поняття допускає багатофакторність, варіативність шляхів розвитку, визнає випадковість, стохастичність в розвитку соціальної системи як природного процесу; нестабільність, нерівноважність як її іманентний стан.

На основі відповідної концептуальної схеми було проведено діагностику сучасного українського суспільства, показано, що ключовими проблемами перехідних суспільств є проблеми соціокультурної ідентифікації, структурного вибору і перспектив модернізації. Концепція багатовимірності дозволила знайти нетрадиційну інтерпретацію ряду принципових помилок на шляху реформ в країні. Головне полягає в редукціоністській стратегії перетворень, що веде до так званого «згортання вимірів», що, у свою чергу, є результатом невідповідності класичного типу соціального мислення, орієнтованого на аналіз усталених соціальних інститутів і лінійних процесів, сучасним реаліям - явищам нестійкості, стохастичності, невизначеності.

Для того, щоб використовувати синергетичну методологію в гуманітарних науках та діяти на основі синергетичних ідей, треба розуміти сенс застосовуваних термінів. Такому розумінню сприяє філософське прояснення такого сенсу. Наталія Кочубей видала в 2008 році монографію «Синергетичні концепти і нелінійні контексти» (Кочубей, 2008), яка стала основою захищеною нею 2009 року докторської дисертації з філософії науки. Дисертація присвячена розгляду синергетичних концептів та їх евристичних можливостей для експлікації сучасних наукових проблем у різних галузях. Потрібно зазначити, що у вітчизняній науці систематичним чином це зроблено уперше. Заслуговує на увагу й те, що дисертантка експлікує значення терміну «нелінійність» як самовплив системи на себе, що також є авторським здобутком. Н.Кочубей визначила основні стани складних систем, показала еволюцію концепту «складність». Викликає науковий інтерес виявлення нею специфіки мережі як складного нелінійного самореферентного комунікаційного середовища на основі компаративного аналізу мереж та систем. Фокусування уваги на даній проблемі має як теоретичний, так і практичний аспект. Перший полягає у тому, що уможливлює виявлення обмеженості системного підходу до зазначених об’єктів. А другий - у розкритті можливостей мережі як феномена інформаційного суспільства. Запропонований в дослідженні методологічний підхід до вивчення синергетичних концептів є не тільки теоретично доцільним, але він має й явний практичний вимір, особливо в соціально-економічному та освітньому контекстах.

В галузі освіти працювали ще кілька членів нашого товариства. Це професори В.С.Лутай, І.М.Предборська, доцент Л.С. Горбунова. Всі вони в різні роки були співробітниками відділу філософії освіти в Інституті ви- 
щої освіти АПН України. Певним підсумком запровадження синергетичних ідей до осмислення освітянських практик стали підготовлені Людмилою Горбуновою монографія «Філософія трансформативної освіти для дорослих: університетські стратегії і практики» та докторська дисертація «Освіта для дорослих: когнітивно-комунікативні стратегії і практики», захищена нею в 2015 році. Ці роботи присвячено проблемі дослідження освіти для дорослих як складного соціального феномену, що постає в контексті формування глобального суспільства як «суспільства знань».

Ця проблема в царині філософських наук в Україні досліджувалась вперше, тому без перебільшення можна виснувати, що дисертантка своєю роботою відкрила новий напрям наукових досліджень, а саме: філософію освіти для дорослих, що постає у комплексі когнітивних і комунікативних проблем сучасності, в контексті релевантних інтелектуальних стратегій та тенденцій становлення нової культури глобального суспільства. Складність і емерджентність процесів у ключових взаємопов'язаних галузях продукування знання - науці і освіті - зробило дослідження гостро актуальним, методологічно затребуваним і евристичним. На підставі проведеного аналізу дисертантка зробила висновок про вимогу трансдисциплінарного і транскультурного спрямування у реформуванні української освіти, відповідно до якого формуються іiі орієнтації на цінності миру і сталого розвитку в межах глобальної культури і глобального громадянства (Горбунова, 2015).

Визначення настанов до створення сприятливого освітнього середовища для самоорганізації людської особистості мало бути доповнене дослідженням внутрішнього світу людської психіки. Термін «психосинергетика» був запроваджений професором І.В.Сршовою-Бабенко. У психосинергетиці мова йде про поняття «психовимірне середовище». Це, перш за все внутрішньо психологічне середовище, яке ми породжуємо. Це складне середовище, воно само себе добудовує, видозмінює. Увагу психосинергетики сконцентровано на пошуку можливостей змінювати стан внутрішньо психологічного середовища, забезпечуючи зменшення стресовості за рахунок оснащення цього середовища засобами самозбереження та самоналаштування у не руйнуючому режимі, тобто його здатність до нового типу адаптації.

Цей тип заснований на понятті «інформаційно-емоційне середовище». Емоційне середовище визначається цінностями, світоглядом - тим , чим користуються люди для уявлення про себе та пред’явлення себе. Інформаційні потоки можуть травмувати людину. Синергетично це можна виразити через поняття «критичний поріг» (Пригожин) та «критична різниця» (Гакен). За виникнення критичної різниці між біологічною та інтелектуальною іпостасями людини можливі як позитивні, так і нега- 
тивні стрибкоподібні зміни. Багато з цих позицій представлені в книзі I.В.Єршової-Бабенко «Психосинергетические стратегии человеческой деятельности» (Ершова-Бабенко, 2005). В цій книзі зокрема мова йде про технологію, яка забезпечує оснащення психічного середовища людини засобами, адекватними синергетичному розумінню психіки як відкритого, нелінійного, здатного до самоорганізації середовища. Точка зору психосинергетики і теоретична, і практична така, що уникнути травми тіла і забезпечити тілу можливість витримувати те, що відбувається в інформаційному емоційно навантаженому світі, можна лише на основі зміни світогляду, мислення, навичок оперування інформацією.

Одеське відділення Українського синергетичного товариства, що активно працювало під керівництвом професора Єршової-Бабенко, регулярно проводило Пригожинські читання, на нашому засідання представлені професорами Лідією Богатою та Іриною Донніковою. Дослідження багатовимірного мислення Л. Богатою спиралось зокрема на досвід нелінійного мислення в синергетиці, та головне, що розгляд цей відбувався у широкому філософському контексті, пов'язаному з роздумами над становленням та розвитком смислу (Богатая, 2010). Видана з ії ініціативи та за ії редакцією колективна монографія «Философия мышления» (Философия мышления, 2013) об’єднала зусилля філософів по проясненню мисленєвих практик складного та нелінійного мислення, розвідок з варіантів визначення багатовимірності мислення у філософії та науці.

Ірина Доннікова (Доннікова, 2005) цікавиться перш за все синергетичними дослідженнями процесів самоорганізації в соціокультурній сфері. Ї̈̈ монографія «Культурогенная сущность социальной самоорганизации», видана в 2011 році, слугувала основою іiі докторської дисертації з філософії.

В кандидатській дисертації Ольги Волик «Постнекласичні перспективи концептуалізації психологічних практик» на основі уявлень про постнекласичний тип раціональності визначено можливість концептуалізації та консолідації психологічних практик на засадах рефлексії над реалізацією в них гуманістичних цінностей, що відкриває перспективи їхнього залучення до психологічної науки в якості складової її емпіричного базису. Ольга Юріївна - практикуючий психолог, зараз вона використовує синергетичні ідеї, надаючи психологічну допомогу переселенцям з зони проведення АТО на Донбасі, працюючи в міжнародній гуманітарній місії.

Гуманістичні цінності знаходились в центрі уваги докторської дисертації Юрія Мєлкова «Людиновимірність постнекласичної науки». Там обгрунтована нова концепція філософського бачення об’єктивності постнекласичної науки, що засновується на визнанні людиномірності наукового пізнання як сучасної історичної форми розвитку об’єктивності. 
Особливість такої форми полягає в її співвіднесеності з людськими цінностями, почуттями та смислами, які не заважають, а допомагають досягненню об’єктивного наукового знання (Мелков, 2014).

По монографії Марії Нестерової «Когнитивистика, истоки, вызовы, перспективы» (Нестерова, 2015), виданої у 2015 році, ще має бути невдовзі захищена докторська дисертація з філософії науки. Її дисертаційне дослідження «Сучасні когнітивні дослідження: філософсько - методологічні контексти концептуалізації» здійснює філософську реконструкцію тенденцій концептуалізації сучасних когнітивних досліджень. Визначено сучасний стан когнітивних досліджень як такий, що являє собою мережу, центровану навколо пов'язаних між собою когнітивних наук та супутніх когнітивних практик та технологій, частина яких є реалізацією когнітивних концепцій, а частина ще не концептуалізовані. Цей конгломерат когнітивних наук, практик і технологій в їх єдності є феноменом постнекласики і в роботі визначений терміном «когнітивістика». Виявлено загальні тенденції концептуалізації когнітивістики в якості гіпермережевого нелінійного утворення та реалізації його трансдисциплінарних стратегій в іiі різних вузлах. Показано, що когнітивістика має нелінійний динамічний характер розвитку з його характерними рисами: відкритістю до середовища (в даному випадку соціуму), зворотними зв'язками, емерджентністю нових утворень, коеволюційними процесами взаємно детермінованих змін. Орієнтація на реалізацію такої установки прослідковується в дисертаційній роботі не тільки на результатах сучасних когнітивних досліджень, а й на прикладі ідей і практик менеджменту, економіки, психології та певних напрямків комп'ютерної науки. Продемонстровано практичне значення застосування когнітивних концепцій в різних предметних сферах; окреслено перспективи подальшої концептуалізації когнітивістики

Я нагадала кілька результатів наукових досліджень членів Українського синергетичного товариства, визнаних науковою спільнотою України, яка присвоїла авторам цих досліджень відповідні наукові ступені. Та наші роботи визнані і міжнародним науковим співтовариством. Наші науковці брали участь у міжнародних наукових проектах: проект IHTAC у співробітництві з колегами з Австрії, Німеччини та Росії «Людські стратегії у складності» (2002-2005), україно-російські проекти «Постнекласика: філософія, наука, культура» (2005-2007) та «Постнекласичні практики у змінному світі» (2008-2010).

Українське синергетичне товариство (http://www.synergetic.org.ua) 2010 року стало колективним членом Берталанфі Центру. Міжнародна громадська організація науковців «Центр системних наукових досліджень Берталанфі (Bertalanffy Center for the Study of System Sciences 
- BCSSS http://www.bertalanffy.org) була заснована 2001 року у Відні (Австрія). Центр входить у Міжнародну федерацію системних досліджень. Ця федерація об'єднує спілки дослідників, які працюють на базі системного підходу в різних галузях науки. 31972 року кожні два роки відбуваються Європейські зібрання науковців щодо кібернетичних та системних досліджень (European Meetings on Cybernetics and Systems Research - EMCSR) для обміну ідеями з приводу нових аспектів розвитку різних наукових дисциплін.

Останнім часом системний підхід набув нового дихання за рахунок досліджень складних систем, здатних до самоорганізації. В зв'язку з цим BCSSS ставить собі за мету подальший розвиток системного мислення, зокрема на основі переосмислення загальної теорії систем, колись заснованої Людвігом фон Берталанфі, на базі врахування досягнень системного підходу, здобутих за пройдений час. Члени Центру Берталанфі вважають, що у світлі сучасних глобальних викликів розвинуті теорії складних систем потрібні, як ніколи. Саме проблеми самоорганізації та розвитку складних систем були в центрі уваги EMCSR (European Meetings Cybernetic and System Resirches). У 2012 року та 2014 році EMCSR зібрання (http://www.emcsr.net) організовував Центр Берталанфi. Українське синергетичне товариство виступило в якості одного 3 його партнерів по організації цих форумів у Відні. У 2012 році президент товариства професор І.С.Добронравова була співголовою симпозіуму А «Складні системи після Е.Морена». 3 доповідями на засіданнях цього симпозіуму виступили, крім неї, члени товариства професори, доктори філософських наук Н.В.Кочубей, І.М.Предборська, кандидат філософських наук Ю.О.Мєлков, а також колеги з Німеччини, Австрії, Греції, Франції. В журналі «Філософія освіти», який редагують члени нашого товариства Л.С.Горбунова та І.М.Предборська, було представлено найбільш цікаві матеріали цього форуму (Філософія освіти, 2012, № 1-2).

У квітні 2014 року Українське синергетичне товариство організувало симпозіум «Україна на перехресті цивілізацій: синергетичний погляд» в рамках чергової конференції EMCSR «Перехрестя цивілізацій: відповідь та відповідальність системних досліджень». Там виступили І.С.Добронравова, І.В.Єршова-Бабенко, О.Ю Волик, Ю.О. Мєлков, Я.М. Чайка. Це був час після перемоги революції гідності і початку анексії Криму та заворушень на Донбасі. Так склалось, що нами було представлено міжнародній науковій спільноті різні позиції в оцінці буремних подій та намагання осмислити їх з синергетичного погляду.

У себе вдома ми регулярно проводимо засідання круглих столів в рамках Днів науки філософського факультету. В матеріалах нашого сайту http://www.synergetic.org.ua представлені результати наших дискусій. 


\section{Любовь Бевзенко}

Интеграция теории сложностей и теории практик как перспектива разворачивания синергетического проекта в социо-гуманитарной плоскости

В своем докладе я хочу акцентировать внимание на некоторой возможности методологического поворота, смены оптики взгляда на смысл того, чем мы занимаемся. Здесь для меня видится определенная перспектива.

В моей любимой книжке «Теория практик» питерских социологов Волкова и Хархордина, авторы отмечают, что на Всемирном социологическом конгрессе 2006 года организаторы, подводя итоги, отметили, что наиболее потенциальными и притягательными для социологического теоретизирования выглядят два направления. Первое привязано, условно говоря, к системному направлению в социологии и призвано дать ответ на вопрос, что происходит в социологии, в ее системном секторе. Что здесь изменилось после Лумана в связи с появлением так называемой complexity theory. Второе направление ищет ответ на вопрос, как продолжает разворачиваться линия французской социологии, условно обозначенная как линия Дюркгейма - Бурдье. Последнюю логично связать с теорией практик во всем ее многообразии. Речь о синергии микро- и макро-уровней социальных процессов, где и само обозначение микро-макро тоже некоторая условность.

Ключевыми словами к тому, что я буду дальше говорить, будут слова «теория сложностей». Именно сложностей, а не сложности. Так я предлагаю назвать то, что происходит в науке после теории систем, системного подхода как методологической платформы. В частности - в социологической науке после Лумана.

Назвав так то, что приходит после теории систем, мы сразу разделяем системное и сложностное мышление. Последнее - это способ мыслить сложности, их динамику. А первое - мыслить системы. Где разница, почему имеет смысл это различать и разводить? Как и «системы», «сложности» универсальное понятие, под которое подпадают особым образом устроенные объекты любой природы.

Ключом к пониманию сути этих объектов для меня была одна фраза, брошенная Ириной Серафимовной на круглом столе в Институте философии: «Сложные системы это не сложенные системы». Классические системы всегда сложены - из подсистем. Хотя все может быть многоступенчато и действительно сложно, но это разложимая на подсистемы сложность. «Несложенная» сложность «сложностей» - нередуцируемая сложность. Мы не можем разложить сложность на более простые составляющие. Метафоры фрактальности, голографичности - именно то, что эту суть сложностей отображает. Но, что интересно, вполне уместно 
говорить о вложенных сложностях, наложенных сложностях. Они как матрешки одна внутри другой, и как бы мы ни усиливали разрешающую способность оптики рассмотрения, мы будем переходить от одной сложности к другой, от одного уровня фрактала к фракталу более глубокого уровня. И разговор о динамике таких сложностей - это разговор о динамике особого качества открытых сред, на которых и возникают подобного рода структуры в результате самоактивности и самоорганизации этих сред.

В случае общества это такая сложность как все человечество, затем сложность отдельного общества. Увеличивая резкость, получаем сложность отдельных сообществ, затем сложность отдельного человека, сложность его повседневных практик, сложность его психики, его нейронной среды и т.д. Ни в одну, ни в другую сторону нет предела, хотя мы можем и не знать, как это называется. Думаю, говорить о «сложностях» вместо «сложности» будет поначалу так ж непривычно, как говорить о «практиках» вместо «практики».

Философия науки сейчас все больше становится социологией, культурологией или даже местами антропологией науки. Нам об этом давно рассказали Кун, Лакатос, Фейерабенд, но мы не очень услышали. Сейчас об этом все более настойчиво говорят Бруно Латур, Джон Ло. Логика развития самого знания существенно нагружается социальной и культурной компонентой. Наука - это одна из социальных игр, где работают разные наши капиталы, и интеллектуальный не всегда оказывается самым весомым. В результате мы можем повышать свой статус в рамках правил игры, но часто собственно научный вклад в повышении этого статуса - далеко не самая важная составляющая. Об этом я говорила не случайно - я снова хочу вернуться к предложенному мною различению систем и сложностей, переходу от теории систем к теории сложностей.

Ориентированная ранее на российскую науку и российские авторитеты (постсоветские реалии), сейчас наша наука все более переориентируется на авторитеты западные. Об этом нужно говорить спокойно и безоценочно - это закономерности жизни того, что Бурдье называет научным социальным полем. Рефлексия по поводу этих закономерностей помогает убрать многие амбиции и иллюзии, проистекавшие из классического видения науки и процессов в ней происходящих. В рамках моих моделей социальных процессов - это проявление социальной самоорганизации. Через разного рода социальные игры, их форматирование и переформатирование эта самая самоорганизация незаметно вовлекает всех нас в свои потоки, организуя наши практики. 


\section{Лидия Богатая}

\section{Синергетическая традиция: попытки переосмысления}

Научное сообщество, которое можно условно назвать «украинской синергетической традицией», явно не исчерпывается теми именами, которые были названы. Мне, к примеру, хочется сказать о человеке, от которого я впервые услышала слово «синергетика». Это мой учитель - профессор Маргарита Степановна Дмитриева. Еще лет за пять до начала формирования киевского и одесского синергетических сообществ в Одессе существовала небольшая группа исследователей, которые организовали работу «Синергетического семинара». Эта группа создавалась одесским математиком, профессором Сергеем Константиновичем Аслановым. Семинары собирались обычно несколько раз в год. Выступали, чаще всего, физики, математики, которые популяризировали синергетические идеи. Профессор М.С. Дмитриева была в этой группе единственным философом, логиком, стремившимся перевести обсуждаемые вопросы в более широкий культурный контекст.

Спустя несколько лет, когда И.В.Ершова-Бабенко организовала практическую деятельность Одесского филиала украинского синергетического общества, Маргарита Степановна принимала активное участия во всех научных проектах этой группы, привлекая к ним своих аспирантов. В 2005 году издала книгу «Синергетика в науке и наука языком синергетики». В этом сборнике собраны ее основные статьи, в которых продумывались фундаментальные синергетические конструкты.

Мне кажется, что эта небольшая историческая справка иллюстрирует факт того, что сторонников развития синергетических идей в Украине, естественно, было гораздо больше, и всех имен мы не можем упомянуть на этой встрече. Но именно эта «множественная поддержка» оказалась чрезвычайно важной.

При этом, видится, не следует умалчивать и другой, весьма характерный факт. Так, к примеру, на одной из последних украинских конференций, в рамках которой обсуждались, в том числе, результаты развития синергетического движения, один из участников заметил, что спустя десятилетия все еще сложно сказать, чем же на самом деле была синергетическая традиция - особенно в ее постсоветском толковании. Совершенно понятно, что это не наука в чистом виде, и, конечно же, не философия. У многих «очень строгих» исследователей вообще возникало искушение отнести синергетику к ряду «вненаучного знания». В отдельных кругах занятия синергетикой расценивались даже как «лженаучная практика» и вызывали скептическую улыбку. Однако так ли на самом деле наивно то, на что тратили интеллектуальные усилия десятки исследователей, работавших в различных дисциплинарных областях? 
Видится, что сейчас настало время «собирать камни», спокойно взвешивая то, что осталось в «чистом остатке» после широкого проекта, который метафорически можно было бы назвать «формирование синергетической парадигмы». При этом сразу же важно сделать ключевое различение: необходимо видеть два весьма отличных итога. Первый касается естественно-математических наработок, сформированных в результате деятельности научных школ И.Р.Пригожина, Г.Хакена, С.П.Курдюмова. Результат второй вызван своеобразной диффузией «чистых синергетических идей» в различные научные сферы, в том числе - в гуманитаристику. Об этом «втором» или побочном результате мне и хочется тезисно высказаться, зафиксировав те наиболее интересные результаты, которые в первую очередь привлекают внимание.

1. Путь синергетики прекрасно иллюстрирует способ функционирования символа (моя кандидатская диссертация была связана с попытками разобраться в том, как «работает» символ). Г.Хакен, выбрав слово синергетика, фактически, ввел в современный интеллектуальный дискурс чрезвычайно важный параметр порядка (слово как символ) (хотя понятно, что параметры порядка не вводят, их, скорее, угадывают). Этот символ во многом предопределил те процессы, которые мы сегодня уже рассматриваем как историю развития синергетических идей.

Синергетика - синергия - взаимо-со-действие. Интересно то, что слово синергия подвергалось детальной, последовательной рефлексии в рамках восточной патристики, и этот своеобразный «выстраданный» итог в сжатом, символическом виде оказался некоторым свернутым смысловым фоном для научных разработок, осуществляемых, в первую очередь, в естественнонаучной и математической традициях. Само слово символически объединило «духовное» и естественнонаучное знание, знание «запада» и знание «востока» (не поэтому ли это слово казалось столь вызывающим для многих?). Главный импульс взаимо-со-действия синергетики направлен на преодоление всевозможных искусственных разделений: дисциплинарного разделения наук, разделения наук о духе и естественно-математических наук, разделения стран, народов, традиций...

Примером удивительной практики синергии видится и образования уникального российско-украинского сообщества исследователей, сообщества нового типа, функционирующего «без генералов». Многие открытые заседания этой группы единомышленников были бесценным подарком для молодых исследователей, которые воочию могли послушать В.И.Аршинова, И.С.Добронравову, О.Н.Астафьеву, В.Г.Буданова и многих других известных фигурантов синергетического движения. Для жителей «научных провинций» подобные встречи были живительным стимулом. 
Результатом плодотворного творческого союза всех «постсоветских синергетиков» оказался выпуск нескольких томов «Синергетической парадигмы». Название этой серии, опять же, кажется символичным. Слово синергетика формировало новую исследовательскую парадигму, в недрах которой складывались представления о меж- и трансдисциплинарности, о постнеклассике и, наконец, о сложности.

Сегодня распространяется мнение о том, что синергетика исчерпала свой исследовательский потенциал, однако - так ли это?

Термин синергия можно толковать в двух смыслах: синергия горизонтальная и вертикальная. Горизонтальный смысл синергии связан с

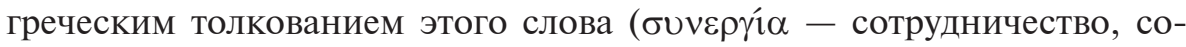
действие, помощь, соучастие, сообщничество,..). Представления о вертикальной синергии предполагает «содействие между различными иерархическими планами». Именно о «вертикальной синергии» размышляли отцы Восточной церкви, видится, что в контексте представлений о вертикальной синергии выстраивает свою концепцию «антропологического размыкания» С.С.Хоружий. Понятно, что у словосочетания «вертикальныя синергия» есть множество прообразов, к примеру «вертикальное восхождение», о котором говорит П.Слотердайк ${ }^{1}$.

«Постсоветская синергетика» (если такой термин имеет право на существование) развивалась под влиянием конструкта «человекомерность», предложенного В.С.Степиным. Однако для развития вертикальной синергетики этот конструкт оказывается явно недостаточным. Вероятно, время пришло говорить о человеко-гео-мерности и о человеко-гео-космо-мернос$m и$. Синергия складывается как результат сознательного взаимодействия человека с планетой, с космосом ${ }^{2}$. На первый взгляд может показаться, что ничего нового в этой мысли нет: освоение человечеством космического пространства, всевозможные экологические движения - это ведь и есть начало развития космо- и планетомерности? Однако хочется подчеркнуть очень важный момент: создание ракет, запуск спутников осуществлялись, во многом, под влиянием классических субъект-объектных парадигмальных представлений. Осваиваемое планетарное и космическое пространства рассматривались как пассивные объекты, здесь не было места «вертикальной синергии». Интуиции К.Э.Циолковского, Н.Н.Федорова оказались востребованными лишь частично (метафори-

${ }^{1}$ Петер Слотердайк. Ти мусиш змінити своє життя (переклад М.Култаєвої) / Філософія освіти. Philosophy of Education. 2014, № 1 (14). - С. 76-95.

${ }^{2}$ Впервые представления о человеко-гео-космо-мерности были введены в публикации: Богатая Л.Н. Проблематизация темы мышления // Философия мышления : [сборник статей] / ред.кол. Л.Н.Богатая, И.С. Добронравова, Ф.В.Лазарев; отв. Ред. Богатая Л.Н. - Одесса : Печатный дом, 2013. - С.163-195. 
Круглий стіл. «Досягнення та перспективи синергетичних досліджень у вітчизняній...

чески - это своеобразная проекция многомерных ментальных размышлений на плоскость). Более глубокое освоение гео - и космо-мерности требует разработки нового концептуального аппарата, основанием для которого могут стать уже наработанные представления о хаосе, информации, виртуальном, актуальном,.. (в размышлениях об актуальном и виртуальном хочется особо отметить удивительный «заключительный философский эскиз» Ж.Делеза «Актуальное и виртуальное»). Лет десять тому назад я делилась с М.С.Дмитриевой мечтой о проведении совершенно необычной конференции, в рамках которой вместе соберутся специалисты, занимающиеся разработкой синергетических идей, идей русского космизма и франиузского постструктурализма (в недрах последнего, во многом, формировались авангардные подходы к пониманию сложного). Но тогда подобная идея казалась «уж слишком неформатной». Возможно, сейчас времена изменились. К примеру, одной из «изюминок» очень важного и полезного сборника «Философия науки в мире сложности» ${ }^{1}$ видятся упоминания Я.И.Свирским о влияниях Ж.Симондона на развитие некоторых идей Ж.Делеза². Что еще раз подчеркивает: развитие современных взглядов на природу сложности (сложностности) едва ли возможно вне углубленного анализа философского постструктурализма.

Российско-украинское синергетическое сотрудничество может и призвано обрести новые направления развития. И это новое возникает в результате взаимо-со-действия, путем вдумчивого прояснения позиций Другого. В этой связи мне кажется уместным упомянуть о многомерном мышлении, представления о котором вызревали в свете идеи о мышлении нелинейном.

Многомерное мышление - это мышление антиредукционное, направленное против огрубляющих упрощений, против одномерных, двумерных проекций многосложной мысли; это вдумчивое, терпеливое проясняющее взращивание мысли Другого, мысли Другого - как своей собственной. Современные информационные завалы формируются, во многом, в результате того, что каждый пытается «выкрикнуть» свое слово, не потрудившись связать его со словом Другого. Здесь кажется очень важным подчеркивание различия многомерности и плюральности. Плюральность лишь утверждает факт существования множественности. Многомерность же - это осваиваемая плюральность. Обнаружить меру мысли Другого - это искусство и труд, но только благодаря этому труду и может созреть мысль собственная. Однако, для того, чтобы измерить

\footnotetext{
${ }^{1}$ Философия науки в мире сложности / Отв. ред.: В.И. Аршинов, Я.И. Свирский // Философия науки. Вып. 18. - М.: ИФ РАН, 2013.

${ }^{2}$ Свирский Я.И. Индивидуализация в сложностно-организованном мире // Философия науки в мире сложности / Отв. ред.: В.И. Аршинов, Я.И. Свирский. - М.: ИФ РАН, 2013. - С. 62-80.
} 
мысль Другого, чтобы раскрыть эту мысль в ее уникальном пространстве смыслов, чтобы суметь одновременно удерживать без редукции, к примеру, размышления Пригожина, Хакена, Курдюмова, нужна сформированная культура многомерного мышления, практика исследования истории мысли. В этой связи Пригожинские чтения, традиция которых сложилась в Одессе под руководством И.В.Ершовой-Бабенко, могут стать площадкой для глубинного проясняющего перепрочтения «культовых» синергетических текстов.

Плюральный и многомерный взгляды на мир весьма различны. Когда мы признаем плюральность, то, фактически делаем половину шага, лишь допуская сам факт существования множества отличных точек зрения. Когда же речь идет о многомерности, то предполагается осознанное погружение в иную мерность, погружения путем измерения познаваемого Другого, освоения без огрубляющих упрощений, без «выкручивания под свою точку зрения», настоящая практика «взаимосодействия» в мысли. Любая междисциплинарность - это подступы к многомерности. Разве это не развитие синергетических идей?

Конечно же, о многомерности мне хотелось бы говорить значительно больше, но важно в рамках отведенного времени обратить внимание еще на один весьма актуальный конструкт, вызревший в недрах синергетики.

2. В своем изначалье синергетика представляла собой естественное развитие системных представлений. Однако со временем исследователи столкнулись с ситуацией необходимости изучения сверхсложных (человекомерных) систем. И как-то постепенно слово система стало отходить на второй план, сложность заявила о себе как нечто такое, что вполне может рассматриваться и вне системных установок. В.И.Аршинов и Я.И.Свирский пытались трансформировать конструкт сложности в сложностность, усиливая при этом внимание на особую роль непрерывно коммуницирующего коллективного субъекта, эту сложность осваивающего ${ }^{1}$. И вот тут, опять же, востребованными оказались постструктуралистские наработки Ж.Делеза и Ф.Гваттари. Появляется возможность моделировать плюральное герменальной множественностью ${ }^{2}$, приблизиться к пониманию которого можно с помощью метафоры мифического непрерывно трансформирующегося Протея.

Плюральное, многомерное, герменальное,.. Все эти термины кажутся весьма комплементарными тому, что именуется сегодня словосоче-

\footnotetext{
${ }^{1}$ Более подробно по поводу толкования сложностности можно посмотреть уже упоминавшуюся выше статью Я.И.Свирского

2 Представления о локальных пространствах смысла как о своеобразных герменальных множествах развивались в публикации: Богатая Л.Н. Мысль и мышление // Філософські проблеми гуманітарних наук. - 2014. - № 24. - С.9-18.
} 
танием «гуманитарный дискурс», но это слова уже из другого научного лексикона. Сложность оказалась тем объектом, при изучении которого возникает необходимость в интеграции естественнонаучного и гуманитарного знания. В этой связи видится чрезвычайно интересным и перспективным развитие представлений о гуманитарной сложности сложности с точки зрения гуманитарных наук.

Опять же, формат проводимого Круглого стола не позволяет углубляться в те наработки по поводу конструкта гуманитарная сложность, которые уже были осуществлены, могу только сослаться на некоторые опубликованные тексты ${ }^{1}$.

Все сказанное хочется заключить следующим. Разговоры о «смерти синергетики», на мой взгляд, являются преждевременными. Символический потенциал слова синергия едва ли полностью исчерпан. Скорее, появляется возможность вывода синергетических разработок на новые уровни, которые связаны, в первую очередь, с осознанной интеграцией гуманитарного и естественнонаучного знания, интеграцией теоретических и практических разработок. Главное «опережение», которое мы сегодня наблюдаем у своих западных и американских коллег связано, в первую очередь, с их стремлением к быстрым практическим использованиям теоретических результатов. И это кажется очень правильным: необходимость «быстрой» интеграции теории и практики. Поэтому я поддерживаю мысль своих киевских коллег о целесообразности завершения наших разговоров за этим «Круглым столом» изданием коллективного сборника текстов, в котором мы сможем более подробно высказаться о том, что выпало «в чистом осадке» после спокойных осмыслений синергетических идей. Хорошо бы, чтобы в этом сборнике были статьи и наших российских коллег.

\section{Ирина Донникова}

Постнеклассическое гуманитарное знание: движение к антропологииеской сложности

Тема «круглого стола» - хороший повод для саморефлексии, для осмысления собственных научных поисков, которые, как теперь представляется, неизбежно привели и к Украинскому синергетическому об-

\footnotetext{
${ }^{1}$ Более подробно представления о гуманитарной сложности развиваются в ряде публикаций, к примеру:

Богатая Л.Н. Гуманитарная сложность в контексте ближайших категориальных понятий // Науковий вісник Міжнародного гуманітарного університету. Серія: Історія. Філософія. Політологія. - Вип.10. - 2015. - С.47-51; Богатая Л.Н. Лингвоэстетика в контексте представлений о гуманитарной сложности // Грані. 2015. - № 11/2 (127). - C.6-11.
} 
ществу и вывели на концепт антропологической сложности. Еще в 90-е годы возникла идея осмыслить культуру как способ самоорганизации жизни людей, как определенную негэнтропийную «технологию», связанную с личностными смыслами человеческого бытия. Эта идея принадлежит моему старшему коллеге и учителю Дорошенко Петру Федоровичу (кстати, выпускнику Киевского университета имени Т.Г. Шевченко 1965 года), с которым мы, работая на кафедре философии Одесской национальной морской академии, обсуждали содержание курса культурологии. Синергетическое понимание культуры складывалось в условиях острого дефицита научных источников по данной проблеме. Это были «знаковые» работы И.Р. Пригожина и И. Стенгерс «Порядок из хаоса: Новый диалог человека с природой» (1986); первая (и единственная на то время) в Украине монография Ирины Серафимовны Добронравовой «Синергетика: становление нелинейного мышления» (1990); перевод отрывка из книги Э. Морена «Утраченная парадигма: природа человека», опубликованный в журнале «Философская и социологическая мысль» (1995); Материалы Московского синергетического форума (1996). А также «первая ласточка» - статья «Культура як феномен самоорганізації ноосфери» А.В. Свидзинского в журнале «Сучасність» (1992). К 2013 году эта небольшая статья выросла в объемную (свыше 700 стр.) монографию «Синергетична концепція культури».

К началу 2000-х круг исследований по синергетике значительно расширился. Возникло особое направление - социальная (и социокультурная) синергетика. Особо следует выделить исследование Л.Д.Бевзенко «Социальная самоорганизация. Синергетическая парадигма: возможности социальных интерпретаций» (2002) - первую в Украине работу по социальной синергетике, которая открыла дорогу исследованиям самоорганизующихся социокультурных феноменов. Сформировался особый методологический инструментарий, получивший совокупное название «синергетический подход к...». Он способствовал разворачиванию междисциплинарного диалога, сохраняя концептуальное единство постнеклассической науки.

Сегодня есть все основания выделять постнеклассическое гуманитарное знание с собственным проблемным полем и методологическим инструментарием, но вместе с тем актуализировать проблему его концептуального самоопределения и перспектив. Следует отметить, что «бессубъектные» теоретические схематизации синергетики не позволяют анализировать индивидуально-личностные, экзистенциальные аспекты бытия человека и культуры. В то же время собственно в философско-культурологическом знании актуальным остается обоснование созидательности культуры, ее востребованности творческодеструктивным по своей сущности человеком. События в новейшей 
Круглий стіл. «Досягнення та перспективи синергетичних досліджень у вітчизняній...

истории Украины только подтверждают необходимость исследования культуры как специфической человекосберегающей «технологии». Такое обоснование, на наш взгляд, возможно в диалоге с синергетикой, которая, к сожалению, для многих гуманитариев остается «чужой». Очевидно, в постнеклассическую исследовательскую программу следует внести концептуальные поправки. На наш взгляд, переход от изучения сложности самоорганизации к самоорганизации сложности позволит расширить проблемное поле постнеклассического гуманитарного знания, сделать его более открытым для философско-антропологической и философско-культурологической проблематики.

Нами предлагается концепт антропологической сложности как концепт-посредник между так называемой аутентичной синергетикой и ее социокультурными приложениями. Он возник в результате осмысления понятий сложности и человекомерности и репрезентует онтологию «антропосоциального развертывания» (Э. Морен), которое невозможно без культуры. Предложенные Э. Мореном принципы сложного мышления могут быть использованы для создания антропосоциокультурной онтологии, в которой человек и культура производят, организуют и изменяют друг друга. В онтологию сложности органично «вписывается» концепт «полисущностного человека», предложенный В.Г. Табачковским (2005). Он позволяет представить человека как сложность, которая, по Морену, есть целостность, раздираемая глубокими внутренними противоречиями. Необходимость их разрешения и вынуждает человека создавать культуру как способ самоорганизации.

Полисущностный человек живет в порождаемом им же онтологическом конфликте, в его бытии действует принцип нарушенной симметрии, что допускает взаимодействие, взаимодополнение противоположных проявлений его сущности. Решая проблему согласования сущности и существования, человек обречен на поиск путей и способов преодоления заложенного в нем конфликта. Тем самым, конфликт не только разъединяет и расщепляет его бытие, но может продуцировать новые ценностные связи, антропокультурные инновации. Он требует культурогенных механизмов сдерживания и стимулирования одновременно. Принципиальная несводимость сущности человека ни к одному из ее проявлений оборачивается для него необходимостью сопряжения разных стратегий исследования мира, определения и одновременно размывания границ культуры, культурного и бескультурного (антикультурного).

На наш взгляд, через осмысление антропологической сложности создается возможность постнеклассической интерпретации ключевых проблем бытия человека, а также расширение стратегий междисциплинарного поиска. 


\section{Юрий Мелков}

Постнеклассические исследования: гуманитарность и гуманистичность

Постнеклассический тип научной рациональности, описанный применительно прежде всего к естественнонаучным дисциплинам, в наши дни окончательно уже утверждается как отображающий в себе характерные особенности исследовательских программ всех отраслей научного познания, позволяя тем самым говорить о преодолении дихотомии «наук о природе» и «наук о духе». Такой яркий феномен постнеклассической науки как синергетика, зародившаяся в области конкретных исследований физики и химии, оказывается вполне уместным методологическим инструментом для изучения общества - подобно тому, как экология превратилась уже из подчинённой дисциплины биологической и зоологической науки в междисциплинарное направление, позволяющее с большей или меньшей мерой метафоричности говорить об «экологии культуры» и «экологии человека».

Можно ли утверждать тем самым о развивающейся - либо даже и состоявшейся - гуманитаризации науки в целом и о воплощении в постнеклассических исследованиях идей философов прошлого, мечтавших об основании научного познания на гуманистических идеалах? По известным словам молодого К. Маркса: «Впоследствии естествознание включит в себя науку о человеке в такой же мере, в какой наука о человеке включит в себя естествознание: это будет одна наука» (Маркс, 1974: с. 124). В конце XX века эти идеи особенно тщательно развивал И. Т. Фролов, формулируя идею «единства науки и гуманизма, в результате которой наука предстаёт как гуманизированная наука, включающая в себя человека в своих исходных и конечных результатах» (Фролов, 1975: с.53).

Подобного рода пафос звучит сегодня не так уж и убедительно, благодаря, в том числе, и постнеклассическим исследованиям, приведшим к осознанию ответственности человека за экологическую катастрофу; более того: факт такого осознания свидетельствует скорее о необходимости «очеловечивания» самого человека. Очевидно, что «гуманизация науки» не тождественна взаимопроникновению гуманитарной и естественнонаучной методологии. С одной стороны, и использование синергетики в гуманитарных исследованиях может подчас означать не более чем попытку механистического - а не гуманистического - рассмотрения человека и его общества - иными словами, попытку некритической экстраполяции естественнонаучной методологии на социальную сферу, приводящую потому к утверждениям о якобы чистой спонтанности, «бессубъектности» И «ценностной нейтральности» процессов самоорганизации социума. С другой стороны, собственно гуманитарные науки ничуть не в меньшей мере подвержены искусу дегуманизации. 
Круглий стіл. «Досягнення та перспективи синергетичних досліджень у вітчизняній...

Иными словами, понятия «гуманитарность» и «гуманитаристика», вынесенные в заглавие тематики нашего сегодняшнего «круглого стола», нисколько не являются тождественными категории «гуманистичность»: они одновременно и противоположны, и дополнительны по отношению к ней. Противоположность эта заключается в том, что гуманитарность означает представление человека в качестве объекта - прежде всего, объекта познания в гуманитарных науках; в отличие от этого, гуманизм выступает признанием человека субъектом ценностей, автономным субъектом целеполагания - и собственно ценностью. Тем не менее, на мой взгляд, именно благодаря постнеклассическим исследованиям появляется возможность осмысления этих понятий как дополнительных, перспектива, так сказать, «гуманизации гуманитаристики»: человекомерность как характерная черта постнеклассической науки (См.: Мелков, 2014) выступает актуальной для гуманитарных наук в той же мере, что и для наук естественных. При этом гуманизация гуманитарных наук оказывается сегодня уже не только мечтой далёких от реальной практики философов, но и действительной тенденцией развития самой науки.

Подобный подход, конечно же, далёк ещё от окончательного своего утверждения в современной истории, экономике или политологии, но основные черты его уже вполне ясно проглядывают в зеркале философской рефлексии.

Интересной попыткой решить эту проблему - и измерить неуловимое, конкретное человеческое счастье как мерило успешности бытия современного государства, обычно скрытое под безликими показателями ВВП, пускай и исчисляемыми «на душу населения», - можно назвать проект «Индекс счастливой планеты» (НPI), который рассчитывается независимыми британскими общественными организациями под показательным девизом «Экономика - как если бы люди и планета чтолибо значили» (Abdallah, 2012).

Результаты, приводимые по странам мира, отображают следующую любопытную картину (Abdallah, 2012). Украина занимает, согласно последнему «Индексу счастливой планеты» 2012 года, незавидное 100-е место из 151-го, располагаясь по соседству с Кенией, Замбией и Суданом.

Впрочем, количественное измерение «счастья» - конечно же, далеко не единственная проблема «гуманистической гуманитаристики». Упомянутое зарождение новых направлений исторической науки ставит немало других методологических вопросов, поскольку «история повседневности» оказывается историей явно феноменологического типа, возвращающей науку чуть ли не на уровень историографии, предшествовавшей классическим концепциям исторического процесса. Целью науки не может являться один только сбор информации, коллекциони- 
рование единичных документальных свидетельств из жизни повседневности; как возможна, да и возможна ли вообще, история как история особенного, не сводящегося ни к закономерностям общности, ни к многообразию несвязанных меж собою единичностей?

Этот вопрос относится уже скорее к сфере философии, чем к области методологии исторической науки. Отечественная философская мысль также обращается к феномену повседневности - ненамного позднее Запада, уже в 1980-х годах, когда на фоне усталости от чрезмерной идеологизации мировоззрения могло казаться, что «счастье каждого простого человека» неизмеримо важнее любых философских конструкций и вообще «гранднарративов», и главная задача любого философского мировоззрения представлялась как чуть ли не самоустранение в пользу пролиферации форм обыденного сознания.

Проблема, однако, заключается в том, что попытка представить обыденность и повседневность в качестве ценностно автономной сферы, то есть сферы, самостоятельно производящей смыслы и ценности собственного существования, неминуемо терпит поражение. Человек не может жить без ориентиров, без «смысла жизни». А потому, самоустранение философов от дела насыщения смыслами сферы повседневности, их замыкание в собственном «учёном дискурсе» с неизбежностью приводит к тому, что формирование смыслов и ценностей жизни человека оказывается занятием совершенно иных субъектов: от квазирелигиозных и паранаучных направлений до чуть ли не криминальных. Парадоксальным образом, попытка представить повседневность в качестве цели и источника смыслообразования приводит к бегству человека от повседневности - и хорошо, если в виртуальную реальность, а не в деструктивную секту и не в наркотический дурман (Мелков, 2009: с. 44-45).

Наиболее очевидно проявляется эта особенность именно в эпохи «бифуркаций», в дни социальных кризисов и потрясений. В подобных ситуациях происходит как бы ценностно-смысловое оголение повседневности: как социальная и политическая жизнь человека лишается привычных подпорок в лице легитимной государственной власти, так и нравственная, ценностно-смысловая сторона повседневной жизни оказывается предоставленной самой себе, ясно демонстрируя свою неспособность производить смыслы и ценности (или - по крайней мере - непомерную трудность решения такой задачи). Ни здравый смысл, ни обычай, ни житейский опыт не выдерживают испытания сложностью жизни в таких условиях. Дело, однако, не только и не столько в неспособности здравого смысла как своего рода имманентного самосознания повседневности, её эрзац-философии, к производству адекватных ситуации смыслов и ценностей, а в дефиците общечеловеческой культуры как основы для самоор- 
Круглий стіл. «Досягнення та перспективи синергетичних досліджень у вітчизняній...

ганизации человеческой личности в кризисных условиях, когда внешние, в том числе и принудительные формы социальной организации исчезают, а новые ещё не созданы или по какой-то причине не функционируют. Лишь благодаря культуре человек в нечеловеческих условиях может остаться человеком, не возвращаясь на уровень первобытной повседневности, лишь культура определяет тот набор смыслов, который может придаваться в том числе и эмерджентным структурам, появляющимся в результате социальной самоорганизации, - и позволяет говорить не только о «сложенности» сложности, не раз упоминавшейся сегодняшними выступающими, но и - что ещё более важно - о «слаженности» этой сложности, о ценностном и смысловом её фундаменте.

Более того: существо отмеченной проблемы, на мой взгляд, заключается в том, что в ситуации социальных кризисов и потрясений происходит прежде всего дегуманизация общественного сознания; последняя часто даже и предшествует реальным кризисам.

Любая война упрощает, дегуманизирует сознание путём его сужения, поляризации, даже архаизации, сводя всё многообразие человеческих качеств к противостоянию по одному только государственному, национальному или ещё какому-либо абстрактному признаку: «мы» - «они», «свои» - «враги». Происходит просто катастрофическая редукция всей сложности, многомерности человека - только к одному из многочисленных его измерений!

В противоположность этому можно было бы указать на перспективу учёта многообразия человеческих идентичностей в единстве идеалов гуманизма. Постнеклассическая методология науки, характеризующаяся человекомерностью и ориентирующая потому на «единство в многообразии», на гуманизм как примат общечеловеческих ценностей перед партикулярными, может потому выступить и в качестве методологической основы для развития истории повседневности как актуального направления современной исторической науки.

В заключение можно вспомнить один известный исторический анекдот. В своё время Наполеон назначил великого физика П.-С. Лапласа на пост министра внутренних дел - но спустя полтора месяца уволил с формулировкой: «За привнесение в политику духа бесконечно малых»... Вполне вероятно, что речь шла о мелочности как о человеческом качестве Лапласа вне какой бы то ни было связи с его естественно-философскими идеями. Однако, на мой взгляд, сегодня и естественная наука, и гуманитаристика, и политика именно впитывают в себя «дух бесконечно малых» - обращаясь от «общей картины», от государства к конкретному человеку как к подлинной ценности, пытаясь тем самым соединить познание человека как объекта с признанием его как субъекта целеполагания и субъекта исторического процесса. 
Л Богатая. Скажите, пожалуйста, а как вообще можно говорить о гуманизме после критики его Ж. Лиотаром?

Ю.Мелков. Дело в том, что в истории философии как понятие, так и идея гуманизма получали самые различные толкования, включая те, которые были подвергнуты справедливой критике в качестве «абстрактного гуманизма». Я употребляю этот термин в наиболее общем значении, не сводимом к тонкостям «атеистического» или «марксистского» гуманизма - как этического и демократического принципа, постулирующего необходимость признания и утверждения ценности каждой человеческой личности, а также, в постнеклассическом его истолковании, как признания приоритета общечеловеческих ценностей и идентичностей перед партикулярными. По моему глубочайшем убеждению, уместность идей гуманизма в этом его понимании нисколько не ставится под сомнение фактом злоупотребления этим термином со стороны различных политических и идеологических сил прошлых лет, но, напротив, ещё более актуализируется в ситуации современной мировоззренческой и мультикультурной сложности.

\section{Віталій Надурак}

Використання синергетичної методології для дослідження феномену суспільної моралі

Протягом останніх десяти років головним предметом моїх наукових досліджень була система суспільної моралі в контексті основних принципів синергетики. В листопаді 2015 року в КНУ імені Тараса Шевченка за цією темою була захищена дисертація на здобуття наукового ступеня доктора філософських наук. Отож цілком доречним в межах пропонованої доповіді буде підведення деяких підсумків цієї роботи, зокрема розповідь про окремі аспекти персонального досвіду використання синергетичної методології для дослідження феномену суспільної моралі.

Однією з головних проблем, з якою довелось зіткнутись в процесі роботи, було скептичне ставлення частини науковців до синергетики в цілому та до можливостей іiі застосування для дослідження феномену моралі. Склалася дещо парадоксальна ситуація, коли, з одного боку, в Україні та світі дослідження у галузі синергетики мають уже тривалу та успішну історію, але водночас для деяких категорій науковців статус синергетики надалі залишається сумнівним. Вони нерідко сприймають їі як сучасний варіант діалектики (тієї іiі історичної варіації, яка претендувала на статус філософської теорії, що прагне пояснити все), або ж закидають їй незастосовність в соціогуманітарних науках, чи, взагалі, відмовляють в науковому статусі.

Чи не головною причиною такого скепсису, на мою думку, є слабка обізнаність багатьох представників наукового цеху саме з базовими 
принципами синергетики та межами їх застосування. Нерідко їх знайомство із синергетикою відбувається на основі неякісних праць, в яких замість дослідження спостерігається «жонглювання» синергетичною термінологією, чи навпаки, фахових робіт, в яких поглиблено вивчається окремий аспект синергетики без представлення в доступній формі іiі цілісної картини. 3 цим пов'язане і бачення синергетики як своєрідної «теорії всього», яку застосовують для пояснення всіх сфер реальності: від матеріального мікросвіту до найвищих злетів людського духу (як-от мораль). Щодо останнього, то презентуючи результати своєї праці перед різноманітною аудиторією, я одразу ж прагну наголошувати на вузькому спрямуванні синергетичної парадигми: пояснити специфічні особливості функціонування складних відкритих систем. Тобто підкреслюю, що синергетика не пояснює широку специфіку різноманітних сфер буття, щодо яких іiі застосовують, а лишень демонструє окремий зріз цих сфер, в якому мають місце системні взаємодії (до того ж за умови, що мова йде про відкриті і складні системи).

Саме цей зріз суспільної моралі був предметом мого дослідження. В руслі такого трактування можливостей синергетики в роботі були описані макро- та мікрорівні системи суспільної моралі та особливості їх взаємодії (принципи підпорядкування, зворотного зв'язку тощо), досліджено відкритість такої системи, нелінійність, нестабільність та ефект самоорганізації, що має в ній місце. Саме такий підхід ми й рекомендуємо іншим дослідникам, які прагнуть застосувати синергетику щодо об’єктів, які раніше не вивчалися з іiі допомогою. Тобто, насамперед, необхідно встановити, що дані об’єкти є складними системами та описати їх макро- та мікрорівні і вищезгадані взаємодії між ними, а потім довести відкритість таких систем, їх самоорганізацію, нелінійність розвитку та нестабільність.

Ірина Добронравовова: Як саме ви описали нелінійність розвитку системи суспільної моралі?

Віталій Надурак: Стосовно системи суспільної моралі принцип нелінійності означає, що вплив на неї певних зовнішніх чинників (релігії, культури в цілому тощо) не дає однозначного відгуку. Це пояснюється не тільки тим, що на неї впливає багато зовнішніх і внутрішніх чинників, які вступають у складну взаємодію, наслідки якої часто не можна вивести як з кожного окремо взятого чинника, так і з їх сукупності, а й тим, що в певні періоди розвитку навіть зовсім незначні випадкові фактори можуть мати на неї вагомий вплив. Тому, якщо ми проведемо мисленнєвий експеримент і уявимо дві системи суспільної моралі, які зазнають впливу однакового середовища, то результат такого впливу 
буде різним. У процесі еволюції сформуються дещо відмінні структури, адже процеси самоорганізації йтимуть різними шляхами і творитимуть, врешті, різні «малюнки» організованих структур. Тому на сьогоднішній день ми можемо спостерігати факт існування різноманітних систем суспільної моралі, властивих різним спільнотам.

\section{Владимир Ратников}

\section{Об определении статуса синергетики в методологической культуре}

К настоящему времени массив исследований в области синергетики как конкретно-научных, так и философско-методологических - разросся настолько, что порою трудно обозреть этот массив в целом, определить его предметные границы. Одни авторы рассматривают синергетические исследования как сугубо естественнонаучные, а другие настаивают на специфичности синергетики. В этом плане может возникнуть вопрос, является ли синергетическая картина мира (или парадигма), которая прокламируется исследователями в области синергетики, частью общей физической картины мира (или парадигмы), либо она являет собой какую-то новую, весьма оригинальную картину мира? Тем самым, актуализируется потребность метасинергетики, объединяющей исследования оснований синергетики, её методологического и научного статуса.

Ещё в 80-е годы Ю.Даниловым и Б.Кадомцевым была опубликована довольно резонансная статья, в которой синергетика была названа X-наукой, где " $X$ ” оказывался не столь уж определённым. Мне кажется, что на сегодняшний день мы не намного продвинулись в расшифровке этого “ $\mathrm{X}$ ”.

Кроме того, порою затруднительно осуществлять научную коммуникацию в рамках синергетических исследований, и прежде всего вследствие трудностей адекватного и эффективного “перевода", интерпретации идей синергетики в иных областях знания и адаптации этих идей в соответствующих конкретно-научных областях, и особенно в области социогуманитарного знания. Эти трудности, а также всё чаще встречающиеся разночтения и серьёзные смысловые неопределённости в используемом концептуальном аппарате, вызывают потребность навести некий "порядок" в логико-концептуальном и методологическом “хозяйстве” синергетики. Тем более, что это “хозяйство” (прежде всего, предметная область и способы её научной репрезентации) имеет в современной науке и другие имена - “нелинейная динамика", “неравновесная термодинамика открытых систем”, “теория детерминированного хаоса”, “наука о сложном”. Иными словами, настало время, на мой взгляд, активизировать метанаучные исследования, призванные осмыслить эпистемологический статус синергетики, её статус в современной методологической культуре, её роль в обновлении традиционных 
Круглий стіл. «Досягнення та перспективи синергетичних досліджень у вітчизняній...

идеалов и норм научной рациональности; т.е. настало время формирования метасинергетики.

Потребность метасинергетики вытекает, на мой взгляд, ещё из одного обстоятельства. Речь идёт о рассмотрении синергетики в контексте соотношения понятий “теория - модель”. Многие авторы наделяют синергетику парадигмальным статусом, включают её в ядро соответствующей (синергетической) научно-исследовательской программы. Однако, как известно, теоретическим ядром парадигмы и научно-исследовательской программы является фундаментальная теория. Под фундаментальной теорией здесь подразумевается такая достаточно общая теория, которая способна порождать теоретические модели, т.е. теоретические системы более конкретные и меньшей степени общности, чем она сама. А можно ли синергетике приписывать такой статус фундаментальной теории - вопрос, по меньшей мере, спорный.

\section{Людмила Горбунова}

Філософія трансформативного навчання дорослих: методологічні можсливості синергетики

Сучасний контекст глобалізації та інформаційно-комунікаційної революції формує свої виклики людині і освіті. Вже давно ведуться науково-теоретичні дискусії щодо мети освіти, а практика викладання в Україні здебільшого інертно тяжіє до давно вже відомої: метою освіти будьякого рівня є оволодіння знаннями, навичками, вміннями. При цьому, чим вище рівень освіти, тим більш специфічними, спеціалізованими, професійними вони мають бути. Мірою освіченості є некритичне прийняття стандартів і норм професійної діяльності. Сам процес навчання відбувається в раціонально-інформативному просторі, ігноруючи особистісно-індивідуальну емоційно-вольову сферу, не залучаючи учнів до процесу співтворчості. Результатом такої освіти є суб’єкт без здібностей до творчості і критичного мислення і навіть без потреби в них, що прирікає його поповнити інертну і маніпульовану масу, яку Ортега-і-Гассет назвав «чорною діркою соціальності». На мій погляд, будь-яка реформа освіти, яка не посилює творчий потенціал особистості, не змінює світоглядні засади іiї культури та їі самоідентифікації, не має сенсу.

Методологічною засадою подолання кризи сучасної освіти може бути нова філософська парадигма освіти, що будується на філософії складності, самоорганізації, або філософії нестабільності, ядром якої виступає синергетика. У своєму короткому виступі я б хотіла акцентувати на двох принципових аспектах у розумінні ролі, яку виконує і може виконувати синергетика як стратегія мислення в освітній сфері. 
По-перше, будучи інтердисциплінарним науково-дослідним проектом в межах постнекласичної науки, синергетика в освіті виступає не тільки як процес новітнього інформативного навчання, що дає нові знання про складність світу та його системні утворення, а, насамперед, як методологічне навчання, яке в змозі забезпечити таку об'єктивну потребу в культурі знань як міждисциплінарна інтеграція. Кінець-кінцем мова йде про об'єднання гуманітарного та природничого знання, про подолання феномену «розірваності мислення», а в прагматичному сенсі - про підготовку випускників вищої школи і закладів післядипломної освіти для дорослих до комплексного вирішення проблеми Людини в швидкоплинному і хаотично-мінливому світі. Саме тому синергетичний образ мислення має набувати все більшого значення в системі вищої освіти, причому не тільки як навчальний предмет, але і як метод навчання. Сьогодні вже існує явний попит на синергетику з боку викладачів, методистів і дидактиків, які розуміють синтетичну роль синергетики і філософії самоорганізації, насамперед, в розвитку діалогу між різними науковими та навчальними дисциплінами як основи для міждисциплінарного і трансдисциплінарного синтезу знань про Людину та усвідомлення іiі нової ролі в світі.

По-друге, синергетика і пов'язана з нею філософія нестабільності і аутопоезису, на мій погляд, дають нам надію і змогу сформувати прагматику нашій дій в складних мережевих структурах інформаціональних суспільств як динамічних переплетеннях «просторів потоків», в його повсюдних переходах, терміналах і перманентних трансформаціях в «позачасовому часі». Вона нам дає науково-обгрунтоване знання про саму структуру процесу трансформації як руху від однієї упорядкованості до іншої через стадію фазового переходу на тлі посилення випадкових флуктуацій і зростання динамічного хаосу. Такий перехід є інваріантним для складних відкритих систем. Раніше він був описаний в соціальній антропології як «обряд переходу» Арнольдом ван Геннепом и Віктором Тьорнером, а пізніше його опис набув свого поширення в соціальній теорії і психології як «структура переходу» з трьома стадіями (прелімінальною, лімінальною і постлімінальною). Хоч змістовно концепт лімінальності глибоко укорінений в історії філософії, починаючи з філософії Платона, і $є$ іiі «першим словом», що посідає своє місце в першому фрагменті Анаксимандра ( «апейрон» як безмежне), синергетика і теорія складності вперше дають його наукове обгрунтування. Завдяки цьому відкриваються перспективи мислення лімінальності як «становлення» порядку із хаосу, як стадії невизначеності, дискомфортної для індивіда, залученого до цього процесу, але такої необхідної для віднайдення нового смислу і порядку, релевантного «флюїдному» контексту складності. 
«Плинність» і нестійкість в минулому «твердих» ієрархічних структур та інститутів, повсюдність процесів переходу та трансформації культур формують потребу у трансформативному навчанні дорослих індивідів, спроможних бути автономними і відповідальними суб’єктами соціальних процесів і практик. Тобто, на питання, якою має бути освіта в суспільстві глобальних трансформацій , «синергетична» відповідь - трансформативною. Професійний підхід до реалізації завдань трансформативного навчання передбачає усвідомлення його складності і ризикованості, а тому вимагає серйозного аналізу процесів трансформації складних систем, їх понятійно-теоретичного інструментарію і міждисциплінарного синтезу, за допомогою якого можливо досліджувати та моделювати процеси індивідуальної трансформації та самотрансформації, включаючи зміни особистісних парадигм та ідентичностей. В цьому процесі роль синергетики і теорії складності важко переоцінити. Актуалізація теоретичного і методологічного потенціалу синергетики в освітніх дослідженнях дозволить розкрити нові перспективи навчання і сформувати нові пошуково-дослідні моделі в області філософії освіти, в тому числі філософії трансформативного навчання дорослих.

\section{Література:}

1. Бевзенко Л.Д. Социальная самоорганизация. Синергетическая парадигма: возможности социальных интерпретаций.К.: Институт социологии НАН Украины, 2002. - 437c.

2. Бевзенко Л. Д. Социальная самоорганизация в теории и практике Майдана / Totalloge-XXI (дванадцятий випуск). Постнекласичні дослідження. Київ: ЦГО НАН України.-2005. 362с. - С.41-78.

3. Богатая Л.Н. На пути к многомерному мышлению. - Одесса: Печатный дом. 2010.

4. Горбунова Л. С. Філософія трансформативної освіти для дорослих: університетські стратегії і практики: монографія / Л. С. Горбунова. - Суми: Університетська книга, 2015. - 710 с.

5. Добронравова И.С. Синергетика: становление нелинейного мышления. К.: Лыбидь, 1990. - 147 с.

6. Добронравова І.С., Фінкель Л.С. Інтерпретаційна спроможність синергетики (на прикладі візуалізованої структури даних про вибори у Верховну Раду України). // «Актуальні пробдеми соціології, психології, педагогіки.», Київ: Видавничий центр Київського університету ім.Т.Шевченка. Вип.1, 2003.- С.4-12.

7. Добронравова И.С. Финкель Л.С. Динамический хаос в социуме как среда социальной самоорганизации. // «Социология: теория, методы, маркетинг», №1, 2005.- С.168-180.

8. Добронравова И.С. Методологические основания действий в условиях нелинейности.// «Культурный контекст социальной самоорганизации». Сборник научных трудов. Киев: Издательско-полиграфический центр «Киевский университет», 2006.- С. 98-106. См. на сайте http://www.synergetic.org.ua 
9. Донникова И. Постнеклассическое гуманитарное знание: границы и возможности // Філософія освіти, № 1, 2015. - С.157-167.

10. Донникова И.А. Культурогенная сущность социальной самоорганизации. Одесса: Печатный дом, 2011. - 280 с.

11. Ершова-Бабенко И. В. Психосинергетические стратегии человеческой деятельности. Одесса: Nova knyha, 2005.

12. Инновационная сложность / отв. редактор Е. Н. Князева. - СПб.: Алетейя, 2016.- 608 c.

13. Каган М.С. Введение в историю мировой культуры. В 2 кн. / Моисей Самойлович Каган. = СПб.: ООО «Издательство “Петрополис"», 2003. Кн. 1. - 368 с.: Кн. 2. $-320 \mathrm{c}$.

14. Каган М.С. Философия культуры / Моисей Самойлович Каган. - СПб.: ТОО ТК «Петрополис», 1996. - 416 с.

15. Кочубей Н.В. Синергетичні концепти і нелінійні контексти. - Суми: Університетська книга, 2009.

16. Маркс К. Экономическо-философские рукописи 1844 года : Пер. с нем. // Маркс К., Энгельс Ф. Сочинения. - М. : Политиздат, 1974. - Т. 42. - С. 41-174.

17. Мелков Ю. А. Философия как культура осмысления повседневности // Философия повседневности : Материалы конференции. - К. : [Б.изд.], 2009. - С. 44-45.

18. Мелков Ю. А. Человекомерность постнеклассической науки. - К.: Изд. ПАРАПАН, 2014. - $254 \mathrm{c}$.

19. Морен Э. Утраченная парадигма: природа человека (отрывки из книги) / Э. Морен // Философская и социологическая мысль - - 1995. - № 5-6. - С. 90 - 109.

20. Московский синергетический форум. Январская (1996) встреча: «Устойчивое равновесие в изменяющемся мире». Тезисы. / Под ред. А.И. Аршинова, Е.Н. Князевой. - М., 1996. - 118 с.

21. Нестерова М.А. Когнитивистика, истоки, вызовы, перспективы. - Суми: Університетська книга, 2015.

22. Постнеклассика: философия, наука, культура - Санкт-Петербург: Издательский дом “МІРЬ”, 2009.

23. Предборская И. М. Влияние синергетических идей на становление неравновесной социодинамики // Практична філософія. 2003. № 1.- С. 113-118.

24. Пригожин И. Порядок из хаоса: Новый диалог человека с природой / И. Пригожин, И. Стенгерс; [пер. с англ.]. - М.: Прогресс, 1986. - 431 с.

25. Свідзінський А.В. Культура як феномен самоорганізації / А.В. Свідзінський // Сучасність. - 1992. - № 4. - С. 141-155.

26. Синергетическая парадигма. «Синергетика инновационной сложности». - М.: Прогресс-Традиция, 2011. - 496 с.

27. Табачковський В.Г. Полісутнісне hото: філософсько-мистецька думка в пошуках «неевклідової рефлективності» / Віталій Георгійович Табачковський. - К.: Видавець ПАРАПАН, 2005. - 432 с.

28. Трансдисциплинарность в философии и науке: подходы, проблемы, перспективы - М.: Институт Философии РАН. Издательский дом «Навигатор» - 2015.

29. Философия мышления - Одесса: «Печатный дом», 2013.

30. Фролов И. Т. Прогресс науки и будущее человека / И. Т. Фролов. - М. : Политиздат, 1975. - $224 \mathrm{c.}$ 
Круглий стіл. «Досягнення та перспективи синергетичних досліджень у вітчизняній...

31. Хакен Г. Принципы работы головного мозга, М., «Per Se», 2001. - 351 с. - C.41-71.

32. Abdallah S. The Happy Planet Index: 2012 Report : A global index of sustainable well-being [Электронный ресурс] / Abdallah S., Michaelson J., Shah S., Stoll L., Marks N. - London : New economics foundation, 2012, - Режим доступа: http:// www.happyplanetindex.org/assets/hpi-data.xlsx.

33. Books of abstracts of EMCSR 2012, 2014 on: http://emcsr.net/book-of-abstracts/

Круглый стол «Достижения и перспективы синергетических исследований в отечественной гуманитаристике» (Киевский национальный университет имени Тараса Шевченко, 17 апреля 2016 года)

В мае 2017 года исполнится 15 лет со дня создания Украинского синергетического общества. Готовясь к своему юбилею, члены этого общества совместно с кафедрой философии и методологии науки Киевского национального университета имени Тараса Шевченко провели заседание круглого стола в рамках международной научной конференции «Дни науки философского факультета - 2016», которая проходила 20-21 апреля в красном корпусе университета имени Шевченко. Тема этого заседания: «Достижения и перспективы синергетических исследований в отечественной гуманитаристике». Предметом обсуждения были следующие актуальные проблемы: синергетика как трансдисциплинарный научный проект, интеграция теории сложности и теории практик как перспектива развития синергетического проекта в социо-гуманитарной сфере, постнеклассическое гуманитарное знание как движение к антропологической сложности, преодоление дегуманизации гуманитарных наук, использование синергетической методологии для исследования феномена общественной морали, методологические возможности синергетики в исследовании образовательных практик, в частности, трансформативного обучения взрослых.

Вела это заседание президент Украинского синергетического общества профессор Ирина Добронравова, доктор философских наук, заведующая кафедрой философии и методологии науки КНУ имени Шевченко.

Ключевые слова: синергетика, трансдисциплинарнисть, теория сложности, теория практик, постнеклассическое гуманитарное знание, Украинское синергетическое общество.

Round table «Achievements and Prospects Synergetics Research in Domestic Humanities" (Taras Shevchenko National University of Kyiv, April 17, 2016)

Ukrainian Synergetics Society would celebrate its 15th anniversary in May, 2017. In preparation for this anniversary, some members of the Society, together with the Department of Philosophy and Methodology of Science Taras Shevchenko National University of Kyiv hold a specific round table during the International Scientific Conference "Days of Science at Faculty of Philosophy - 2016", which was hold on April 20-21, 2016 at the red building of Kyiv Taras Shevchenko National University. The title of this round table was "Achievements and Prospects of synergetics research in domestic humanities." The subject of discussion were 
the following topical issues: Synergetics as a transdisciplinary research project, Integration of complexity theory and theory of practices as the prospect of synergetics project development in social-humanitarian sphere, Post-nonclassical humanities as a movement to an anthropological complexity, Overcoming of dehumanization in human sciences, Using of synergetics methodology for study of public morality phenomenon, Methodological possibilities of synergetics in educational research practices, particularly in transformative adult education.

Professor Iryna Dobronravova, President of the Society and Head of Department of Philosophy and Methodology of Science of Taras Shevchenko National University of Kyiv was moderated discussion during this round table.

Keywords: synergetics, transdisciplinarity, complexity theory, practices theory, post-nonclassical humanitarian knowledge, Ukrainian Synergetics Society.

До друку підготувала Людмила Горбунова

Добронравова I.C. - д.філос.н., проф., завідувач кафедри філософії та методології науки Київського національного університету імені Тараса Шевченка;

Бевзенко Л.Д. - Д.соц.н., ст. наук. співробітник Інституту соціології НАН України;

Богатая Л.Н. - д.філос.н., проф. кафедри культурології філософського факультету Одеського національного університету імені I.І.Мечнікова;

Горбунова Л.С. -Д.філос.н., провід.наук. співробітник Інституту вищої освіти НАПН України;

Доннікова І.А. - д.філос.н., проф. кафедри філософії національного університету «Одеська морська академія»;

Мєлков Ю.А. - д.філос.н., завідувач кафедри філософії міжрегіональної академії управління персоналом;

Надурак В.В. - д. філос. н., доцент кафедри філософії та соціології Прикарпатського національного університету імені В.Стефаника;

Ратніков В.С. - д.філос.н., проф., проф. кафедри філософії Вінницького політехнічного університету. 